\title{
A New Host-Plant for Larvae of Hellula undalis (Fabricius, 1781) in Turkey (Lepidoptera: Crambidae)
}

\author{
Kesran AKIN*1, Erdem SEVEN ${ }^{2}$ \\ ${ }^{1}$ Bitlis Eren University, Faculty of Arts and Sciences, Department of Biology, 13000, Bitlis, Turkey \\ ${ }^{2}$ Department of Gastronomy and Culinary Arts, School of Tourism and Hotel Management, Batman University, \\ 72060 Batman, Turkey
}

\begin{abstract}
In this study, Reseda aucheri subsp. rotundifolia (Kotschy ex Müll.-Arg.) (Resedaceae) has been detected the first time as a new host-plant of Hellula undalis (Crambidae). Information on the distribution of H. undalis and its known host-plants are given. Caterpillar, pupa and adult of the species and new host-plant are illustrated.
\end{abstract}

Keywords: Hellula undalis, Reseda aucheri subsp. rotundifolia, host-plant, Batman, Turkey.

\section{Hellula undalis (Fabricius, 1781) Larvaları İçin Türkiye'den Yeni Bir Konukçu Bitki (Lepidoptera: Crambidae)}

$\ddot{O} \mathbf{z}$

Bu çalışmada Reseda aucheri subsp. rotundifolia (Kotschy ex Müll.-Arg.) (Resedaceae) ilk kez Hellula undalis (Crambidae)'in yeni konukçu bitkisi olarak tespit edilmiştir. H. undalis'in yayılışı ve bilinen konukçu bitkileri hakkında bilgi verilmiştir. Türün tırtıl, pupa ve ergin bireyi ile yeni konukçu bitkisi resmedilmiştir.

Anahtar kelimeler: Hellula undalis, Reseda aucheri subsp. rotundifolia, konukçu bitki, Batman, Türkiye.

\section{Introduction}

The subfamily Glaphyriinae belongs to the family Crambidae is known with 345 species in the world [1]. In study of the phylogenetic classification of Pyraloidea by Reiger et al. [2], they mentioned Evergestinae and Noordinae were synonyms of Glaphyriinae and stated that the most distinctive features of these groups, the larvae of many of genera fed on mustard oil containing plants belonging the order of Brassicales.

Hellula undalis (Fabricius, 1781) is distributed in Europe, Africa, large part of Asia, Australia and Pacific Islands [3]. In Turkey, the species is known from Adana, Bitlis, Bursa, Gaziantep, Hakkâri, Hatay, İzmir, Mersin, Kahramanmaraş, Van, Şırnak and Düzce provinces [4-6]. It is generally known as a pest of crucifers, and so far known host-plants are as follows: Armoracia rusticana, Brassica caulorapa, B. chinensis, B. juncea, B. nigra, B. oleracea, B. parachinensis, B. rapa, Coronopus sp., Diplotaxis sp., D. pendula, Moricandia sp., M. arvensis, M. suffruticosa, Raphanus sp., R. sativus, Rorippa sp. Sinapis alba (Brassicaceae (Cruciferae)); Cleome sp., C. arabica, C. gynandra, C. rutidosperma, C. viscosa, Polanisia sp. (Capparaceae); Clitoria sp. (Fabaceae); Hygrophila salicifolia (Acanthaceae) [7-10].

On the biology of $H$. undalis, an important study was carried out by Yabaş and Zeren [5] in Turkey. They stated that in the field studies, the adult specimens emerged from the second half of June, the population reached the highest level in August and September, and the population decreased gradually following in October. In addition, they stated that the species has 5 generations and there are

*Sorumlu yazar: kesran@gmail.com

Geliş Tarihi:05.12.2018, Kabul Tarihi: 18.01.2019 
15-20 days between each generation depending on temperature and the adults of 5th generation emerge in 36 days.

Reseda aucheri Boiss. subspecies rotundifolia (Kotschy ex Müll.-Arg.) Rech. f. is known as "dicle gerdanlığı" in Turkey [11]. R. aucheri is distributed in Turkey, Iran, Iraq, Afghanistan, India and Pakistan [12]. It is used to remove the toxicity and sensitivity of bites of snake, insect and scorpions in Iran [13].

The aim of this study is to contribute to the host-plant and distribution of $H$. undalis from southeastern Turkey.

\section{Materials and Methods}

The materials of the study consist of the larvae of collected by the second author on the R. aucheri subsp. rotundifolia from Bat1 Raman Campus of Batman University, Batman, Turkey (Figure 1), at $625 \mathrm{~m}$, in $37^{\circ} 47^{\prime} 17^{\prime \prime} \mathrm{N}, 41^{\circ} 03^{\prime} 53^{\prime \prime} \mathrm{E}$ coordinates. The location is rich in herbaceous plants and, $R$. aucheri subsp. rotundifolia is intensively located in the habitat. During the researches in the field, a large amount of $H$. undalis larvae were found on the plants and six of these larvae were collected on 17.08.2018 for examination. After the feeding in the laboratory conditions, the larvae pupated on 23.08.2018 and, consequently, after 10 days only two adult specimens (high possibility due to hot and dry laboratory conditions, approx. $45^{\circ} \mathrm{C}$ ) emerged from pupas on 03.09.2018 (Figures 2-5). The adult specimens were identified by the first author. The larvae of the species were determined on the plant, over a long period of time from beginning of summer and to the nearly end of autumn, in the study region.

\section{Results and Discussion}

$H$. undalis, as mentioned above, feeds usually with plants belonging to the family of Cruciferae. Mewis et al. [8] stated that the species was sensitive to density of glucosinolate compound, which is a characteristic compound for the family of Cruciferae. They reported that this compound attracted female of H. undalis. Besides, Kalbfleisch [9] stated that this compound was detected in Brassicaceae and Capparidaceae and in other close families: Tovariaceae, Resedaceae, Tropaeolaceae and Limnanthaceae. On account of these, we think that most likely, the feeding of $H$. undalis with $R$. aucheri subsp. rotundifolia (Resedaceae), related to the compound of glucosinolate, which is noted by Mewis et al. [8] and Kalbfleisch [9].

According to the literature, members of Resedaeae family have not been reported as the hostplant for $H$. undalis. As results of this research, $R$. aucheri subsp. rotundifolia, belonging to Resedaceae family, is detected for the first time as a new host-plant for the species. Additionally, this study is contributed to distribution of $H$. undalis as it is discovered for the first time in Batman province.

\section{Acknowledgements}

We are grateful to Dr. Mehmet FIDAN (Siirt University, Turkey) for identification of host-plant.

\section{References}

[1] Nuss M., Landry B., Mally R., Vegliante F., Tränkner A., Bauer F., Hayden J., Segerer A., Schouten R., Li H., Trofimova T., Solis M.A., De Prins J., Speidel W. 2003-2017: Global Information System on Pyraloidea. www.pyraloidea.org. (Access date: 04.10.2018).

[2] Reiger J.C., Mitter C., Solis M.A., Hayden J.E., Landry B., Nuss M., Simonsen T.J., Yen S., Zwick A., Cummings M.P. 2012. A Molecular Phylogeny for The Pyraloid Moths (Lepidoptera: Pyraloidea) and Its Implications for Higher-Level Classification, Systematic Entomology, 37: 635656.

[3] Waterhouse D.F., Norris K.R. 1989. Biological Control: Pacific Prospects- Supplement 1. ACIAR Monograph No. 12 , vii +123 p.

[4] Koçak A.Ö., Kemal M. 2018. A synonymous and distributional list of the species of the Lepidoptera of Turkey, Centre for Entomological Studies, Memoirs, 8: 1-487. 
[5] Yabaş C., Zeren O. 1987. Lahana Göbekkurdu (Hellula undalis F.) (Lepidoptera: Pyralidae)'nun biyolojisi üzerinde araştırmalar. Türkiye I. Entomoloji Kongresi, pp229-238, 13-16 Ekim, İzmir.

[6] Yabaş C., Zeren O. 1990. Doğu Akdeniz Bölgesinde Lahana Göbekkurdu (Hellula undalis Fab.) (Lep.: Pyralidae)'nun Biyoekolojisi ve Mücadelesi Üzerinde Araştırmalar. T.C. Tarım ve Köyişleri Bakanlığı, Tarımsal Araştırmalar Genel Müdürlüğü, Bitki Koruma Araştırmaları Daire Başkanlığı, Zirai Mücadele Araştırma Y1llığı, 24-25: 30-31.

[7] Robinson G.S., Ackery P.R., Kitching I.J., Beccaloni G.W., Hernández L.M. 2010. HOSTS - A Database of the World's Lepidopteran Hostplants. Natural History Museum, London. http://www.nhm.ac.uk/hosts. (Access date: 05.10.2018).

[8] Mewis I., Ulrich Ch., Schnitzler W.H. 2002. The role of glucosinolates and their hydrolysis products in oviposition and host-plant finding by cabbage webworm, Hellula undalis, Entomologia Experimentalis et Applicata, 105: 129-139.

[9] Kalbfleisch S. 2006. Integrated Pest Management of Hellula undalis Fabricius on Crucifers in Central Luzon, Philippines, with E, E-11, 13-hexadecadienal as Synthetic Sex Pheromone. Doctoral thesis, Technisch Universität München, 184 p.

[10] Goff R. 2018. Hellula undalis (Fabricius, 1781). African Moths. https://www.africanmoths.com/pages/CRAMBIDAE/GLAPHRYIINAE/hellula\%20undalis.html. (Access date: 08.10.2018).

[11] Anonymous, 2018. Türkiye Bitkileri Listesi, Gerdanlık (Reseda). http://www.bizimbitkiler.org.tr/v2/hiyerarsi.php?c=Reseda. (Access date: 02.10.2018).

[12] Efloras, 2018. Flora of http://www.efloras.org/florataxon.aspx?flora_id=5\&taxon_id=25006464.

Pakistan. 02.10.2018).

[13] Safa O., Soltanipoor M.A., Rastegar S., Kazemi M., Dehkordi K.N., Ghannadi A. 2013. An ethnobotanical survey on Hormozgan province, Iran, Avicenna Journal of Phytomedicine, 3(1): 6481 . 


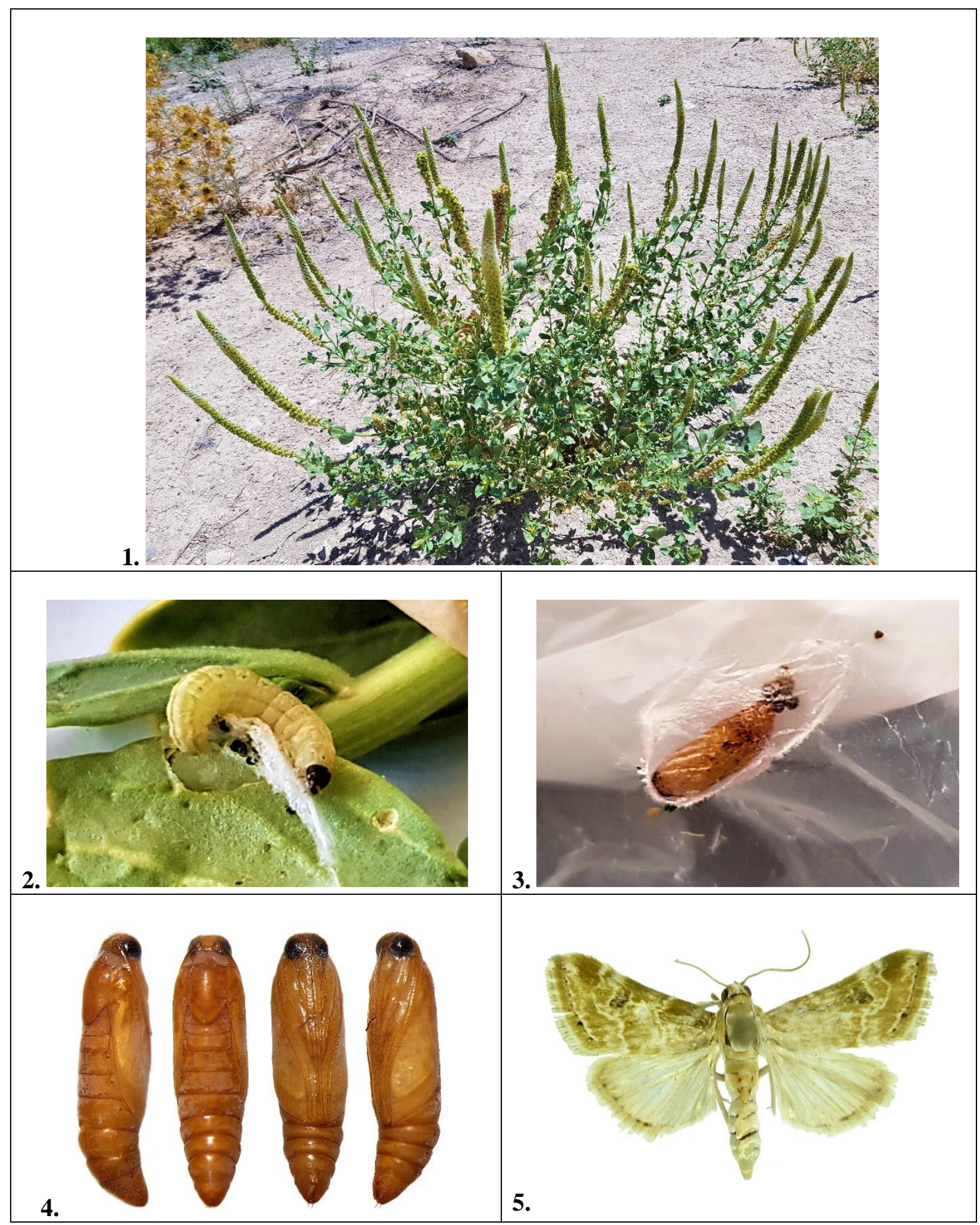

Figures: 1. The host-plant, $R$. aucheri subsp. rotundifolia, 2-5. Stages of H. undalis, 2. Larva, 3-4. Pupa, 5. Adult 